\title{
Studi Ketimpangan Sosial Ekonomi Pada Wilayah Pesisir Kecamatan Labakkang Kabupaten Pangkep
}

\section{Study of Social Economic Inequality in Coastal Area of Labakkang District Pangkep Regency}

\author{
Muhammad Rizal Rahman ${ }^{1}$, Agus Salim², Muh. Iqbal Samad Suhaeb ${ }^{2}$ \\ ${ }^{1}$ Magister Program Studi Perencanaan Wilayah dan Kota Program Pascasarjana Universitas Bosowa \\ ${ }^{2}$ Program Studi Perencanaan Wilayah dan Kota Program Pascasarjana Universitas Bosowa \\ E-mail: ichalmuhrizal@yahoo.com
}

Diterima: 11 Januari 2020/Disetujui 05 Juni 2020

\begin{abstract}
Abstrak. Penelitian ini bertujuan untuk mengkaji dan menganalisis karakteristik ketimpangan dan pengaruh perkembangan kawasan pesisir terhadap kondisi sosial ekonomi masyarakat Kecamatan Labakkang Kabupaten Pangkep. Penelitian ini bersifat deskriptif kuantitatif dengan menggunakan alat analisis yaitu koefisien gini (gini ratio) atau indeks gini dan analisis regresi linear berganda. Data diperoleh dari Badan Pusat Statistik Daerah Kabupaten Pangkep, Dinas Penataan Ruang Kabupaten Pangkep, Kantor Kecamatan Labakkang, Kantor Kelurahan Pundata Baji dan masyarakat kelurahan Pundata Baji yang bertindak sebagai responden. Penelitian ini terdiri dari lima variabel bebas (independent) yaitu pendapatan (X1), pendidikan (X2), akses modal (X3), sarana dan prasarana (X4) dan pekerjaan (X5), sedangkan variabel terikatnya (dependent) adalah kondisi sosial ekonomi masyarakat (Y).. Hasil penelitian menunjukkan bahwa karakteristik ketimpangan sosial ekonomi pada kawasan pesisir Kecamatan Labakkang Kabupaten Pangkep berada pada nilai tingkat ketimpangan sedang. Dengan demikian, adanya tingkat ketimpangan yang sedang di Kelurahan Pundata Baji menggambarkan bahwa adanya kesenjangan pendapatan di antara masyarakat, utamanya masyarakat yang bermukim pada wilayah pesisir. Sedangkan pengaruh perkembangan kawasan pesisir terhadap kondisi sosial ekonomi masyarakat dipengaruhi secara signifikan oleh faktor pendidikan dan sarana prasarana. Hal ini dikarenakan semakin pesatnya minat pemerintah daerah terhadap peningkatan keterampilan mutu sumber daya manusia SDM melalui program SPP gratis untuk para pelajar. Kemudian, hal tersebut juga memicu berkembangnya pembangunan dengan kebijakan pemerintah pusat dan daerah terhadap peningkatan infrastruktur. Namun tidak terdapat pengaruh secara signifkan atas perkembangan kawasan pesisir di Kecamatan Labakkang Kelurahan Pundata Baji Kabupaten Pangkep terhadap faktor pekerjaan, akses modal dan pendapatan daerah tersebut.
\end{abstract}

Kata Kunci: Ketimpangan Pembangunan, Sosial Ekonomi, Masyarakat Pesisir, Pangkep

\begin{abstract}
This study aims to examine and analyze the characteristics of inequality and the influence of the development of coastal areas on the socio-economic conditions of the community in Labakkang District, Pangkep Regency. This research is descriptive quantitative using analytical tools, namely the Gini coefficient (Gini ratio) or Gini index and multiple linear regression analysis. The data were obtained from the Statistics Indonesia in Pangkep Regency, the Spatial Planning Office of Pangkep Regency, the Labakkang District Office, the Pundata Baji Village Office and the people of Pundata Baji Village as the respondents. This study consists of five independent variables, namely income (X1), education (X2), access to capital $(X 3)$, facilities and infrastructure (X4) and employment (X5), while the dependent variable is the socio-economic conditions of the community $(Y)$. The results showed that the characteristics of socio-economic inequality in the coastal area of Labakkang District, Pangkep Regency were at a moderate level of inequality. Thus, the moderate level of inequality in Pundata Baji Village illustrates that there is an income gap among the community, especially those who live in coastal areas. Meanwhile, the influence of the development of coastal areas on the socio-economic conditions of the community is significantly influenced by the factors of education and infrastructure. This is due to the increasing interest of local governments in improving the quality skills of human resources through the free tuition program for students. Then, this also triggers the improvement of the development through central and regional government policies towards infrastructure improvement. However, there is no significant influence on the development of the coastal area in Labakkang Subdistrict, Pundata Baji Village, Pangkep Regency on the factors of employment, access to capital and regional income.
\end{abstract}

Keywords: Development Inequality, Social Economy, Coastal Communities, Pangkep

\section{Pendahuluan}

Ketimpangan pembangunan antar daerah dengan pusat dan antar daerah satu dengan daerah lain merupakan suatu hal yang wajar, karena adanya perbedaan dalam sumber daya dan awal pelaksanaan pembangunan antar daerah. (Williamson, 1965, dalam Hartono, 2008). Menurut Todaro (2004), Ketimpangan antar wilayah dalam kenyataannya tidak dapat dihilangkan dalam proses pembangunan suatu daerah. Dengan adanya ketimpangan, maka akan mendorong daerah yang terbelakang untuk dapat berusaha meningkatkan kualitas pembangunannya 
agar tidak tertinggal dengan daerah yang sudah maju. Selain dampak positif dari adanya ketimpangan dalam pembangunan, adapun dampak negatif yang ditimbulkan yaitu dengan semakin tingginya ketimpangan antar wilayah maka akan semakin terjadi inefisiensi ekonomi, sehingga melemahkan stabilitas sosial dan solidaritas, serta ketimpangan yang tinggi pada umumnya dianggap tidaklah adil (Nasaruddin et al., 2019). Beberapa faktor utama yang menyebabkan atau memicu terjadinya ketimpangan pembangunan wilayah tersebut (Sjafrizal, 2008), adalah : Faktor geografis, historis, politis, kebijakan, administratif, sosial, dan ekonomi.

Kemiskinan merupakan masalah yang muncul ketika seseorang atau sekelompok orang tidak mampu mencukupi tingkat kemakmuran ekonomi yang dianggap sebagai kebutuhan minimal dari standar hidup tertentu. Dalam arti proper, kemiskinan dipahami sebagai keadaan kekurangan uang dan barang untuk menjamin kelangsungan hidup. Dalam arti luas. Chambers (1983) mengatakan bahwa kemiskinan adalah suatu intergrated concept yang memiliki lima dimensi, yaitu: 1) kemiskinan , 2) ketidakberdayaan, 3) kerentanan menghadapi situasi darurat 4) ketergantungan, dan 5) keterasingan baik secara geografis maupun sosiologis. Dalam hal ini masyarakat pesisir atau pedalaman sering dicirikan sebagai masyarakat yang terbelakang, teralienasi, atau terabaikan. Dalam berbagai indikator pembangunan sosial ekonomi, mereka sering berada pada struktur terbawah. Mereka juga sering kali tidak memiliki akses terhadap pelayanan dasar dan informasi. Dengan kata lain bahwa masyarakat pesisir atau pedalaman memiliki ciri-ciri yang berhubungan dengan pola hidup tradisional yang senantiasa menempati stratum terendah dalam lapisan masyarakat (Utomo, 2014). Secara normatif, seharusnya masyarakat pesisir merupakan masyarakat yang sejahtera mengingat besarnya potensi sumber daya alam pesisir dan laut. Namun kenyataan menunjukkan bahwa sebagian besar masyarakat pesisir, terutama nelayan masih merupakan bagian dari masyarakat yang tertinggal. Persoalan kerawanan sosial-ekonomi, seperti kemiskinan, kesenjangan sosial, keterbatasan akses pendidikan dan kesehatan, kelembagaan sosial yang lemah, serta kesulitan akses modal usaha, teknologi dan pasar, merupakan permasalahan yang bersifat multidemensi (kompleks) dan saling terkait satu dengan lainnya (Roslinawati, 2013).

Kondisi geografis Kabupaten Pangkajene dan Kepulauan merupakan daerah dengan tiga jenis karakteristik wilayah yang berbeda-beda kondisi alamnya (dikenal sebagai daerah tiga dimensi) daerah merupakan daerah kaya sumber daya alam, daerah yang berada pada dataran rendah akan kaya dengan produksi Tanaman pangan, budi daya tambak dan hortukultura, sedangkan untuk daerah yang berada diwilayah kepulauan sangat kaya akan potensi hasil lautnya serta daerah yang berada didaerah pengunungan juga potensi untuk tanaman pangan, sayur-sayuran, kehutanan, pertambangan dan penggalian serta menjadi pusat kegiatan industri khususnya industri semen dan industri batu marmer di kawasan timur Indonesia. Kondisi alam dan sumberdaya yang ada telah menjadikan Kabupaten Pangkajene dan Kepulauan menjadi salah satu penopang perekonomian Sulawesi Selatan. Secara umum persentase PDRB Kabupaten Pangkep Tahun
2012-2016, menempati posisi ke 3 (tiga) sebagai wilayah yang memiliki konstribusi sebesar 5,43 \% setelah Kota Makassar dan Kabupaten Bone. Sedangkan, angka kemiskinan Kabupaten Pangkep Tahun 2010 sampai tahun 2013 terjadi trend penurunan. Jumlah penduduk miskin berjumlah 58.872 jiwa pada tahun $20_{1} 0$ atau $16,62 \%$ namun menurun menjadi 56.400 jiwa namun secara persentase meningkat atau 17,75 \% pada tahun 2013. Presentase jumlah kemiskinan di Kabupaten Pangkep hingga tahun 2013 berada di posisi teratas dibandingkan seluruh kabupaten/kota se-Sulawesi Selatan, sementara diurutan kedua adalah Toraja Utara 16,53 \% dan Jeneponto $16,52 \%$. Pada tahun 2014, data BPS Pangkep menunjukkan masih di posisi tertinggi $16,38 \%$ atau sekitar 52.600 jiwa hingga tahun 2016, tingkat presentase garis kemiskinan di Kabupaten Pangkajene merupakan wilayah dengan persentase penduduk miskin tertinggi di Provinsi Sulawesi Selatan sebesar 16,22\%. erdasarkan kondisi tersebut, salah satu wilayah yang menjadi ketimpangan sosial ekonomi masyarakat pesisir di Kabupaten Pangkep adalah di Kelurahan Pundata Baji Kecamatan Labakkang.

Kecamatan Labakkang adalah satu dari 13 Kecamatan di Kabupaten Pangkep Provinsi Sulawesi Selatan, terletak di pesisir pesisir pantai timur Kecamatan Liukkang Tupabiring. Posisi gugusan astronominya antara $40^{\circ}-45^{\prime}$ lintang selatan dan $11^{\circ}-12$ " bujur timur dan barat. Secara administrasi, Kecamatan Labakkang berbatasan sebelah utara dengan wilayah Kecamatan Ma'rang, sebelah selatan dan timur dengan wilayah Kecamatan Bungoro dan sebelah barat dengan wilayah Kecamatan Liukang Tupabiring. Secara geografis, luas wilayah Kecamatan Labakkang 98,46 Km2, luas wilayah tersebut merupakan 8,85\% dari luas wilayah Kabupaten Pangkep. Secara umum sebagian besar mata pencaharian masyarakat di wilayah pesisir Kelurahan Pundata Baji Kecamatan Labakkang adalah nelayan. Keluarga nelayan merupakan keluarga yang sumber mata pencahariannya di laut sebagai sumber penghasilan untuk pemenuhan kebutuhan sehari-hari. Dengan demikian sebagian besar tingkat pendidikan keluarga nelayan di Kelurahan Pundata Baji tergolong rendah, dikarenaka sebagian ada lulusan SD, SMP dan sederajat.

Selain itu juga puluhan warga yang bermukim di kampung nelayan, mengeluhkan sulitnya mendapatkan suplai air bersih. Sehingga warga harus mengantri di depan sebuah bak penampungan untuk mendapatkan suplai air bersih. Dengan demikian pentingnya sebuah kajian terhadap ketimpangan sosial ekonomi masyarakat pesisir di wilayah Kelurahan Pundata Baji Kabupaten Pangkep dikarenakan kondisi masyarakat yang sebagian besar memiliki pendapatan yang diperoleh dari bekerja tidak cukup untuk memenuhi kebutuhan hidup keluarga yang semakin bertambah, karena masyarakat tersebut pada umumnya mata pencaharian utamanya yakni menangkap ikan yang pendapatan setiap keluarga dalam sehari tidak menentu sehingga hasil potensi alam yang didapatkan oleh masyarakat tidak dapat bersaing dengan potensi lokal yang ada di Kabupaten Pangkep.

Adanya perbedaan pasar, keterbelakangan infrastruktur dan kurangnya modal menyebabkan rendahnya produktivitas. Rendahnya produktivitas akan berakibat kurangnya pendapatan yang diterima. Rendahnya 
pendapatan akan berdampak terhadap rendahnya tabungan dan investasi. Rendahnya investasi akan berakibat pada keterbelakangan. Kondisi saat ini tingginya angka kemiskinan di Kabupaten Pangkajene dan Kepulauan sangat kontradiktif terhadap pertumbuhan ekonomi dan produk domestik regional bruto (PDRB) per kapita Pangkep yang merupakan salah satu tertinggi di Provinsi Sulawesi Selatan. Kondisi demikian yang perlunya kajian untuk mengkaji kondisi sosial ekonomi masyarakat Kelurahan Pundata Baji Kabupaten Pangkep . Dengan demikian, penelitian ini sangat menarik untuk dikaji dan dibahas sebagai bentuk penelitian ilmiah yang dilakukan terhadap isu ketimpangan yang terjadi antara besarnya potensi produksi sumberdaya alam Kabupaten Pangkep terhadap tingginya angka kemiskinan yang terjadi, maka fokus dalam penelitian ini yaitu mengkaji karakteristik tingkat ketimpangan sosial ekonomi pada kawasan pesisir Kelurahan Pundata Baji dan menganalisis pengaruh secara signifikan perkembangan kawasan pesisir terhadap kondisi sosial ekonomi masyarakat di Kelurahan Pundata Baji Kecamatan Labakkang terhadap tingginya angka kemiskinan di Kabupaten Pangkep yang tiap tahunnya mengalami presentase teratas di Provinsi Sulawesi Selatan. Penelitian ini bertujuan untuk mengkaji dan menganalisis karakteristik ketimpangan dan pengaruh perkembangan kawasan pesisir terhadap kondisi sosial ekonomi masyarakat Kecamatan Labakkang Kabupaten Pangkep.

\section{Metode Penelitian}

a. Jenis Penelitian

Penelitian ini merupakan penelitian kuantitatif, yaitu penelitian yang menghasilkan berupa angka statistik. Penelitian ini merupakan penelitian korelasional, yang bertujuan untuk mengkaji sejauh mana variabel berpengaruh terhadap suatu faktor yang berkaitan dengan satu atau lebih faktor lain berdasarkan pada koefisen korelasi. Penelitian ini mengukur tingkat distribusi pendapatan yang menunjukkan seberapa meratanya pendapatan dan kekayaan didistribusikan di antara masyarakat Kelurahan Pundata Baji dan mencari pengaruh secara signifikan perkembangan kawasan pesisir terhadap kondisi sosial ekonomi masyarakat di Kecamatan Labakkang Kabupaten Pangkep.

\section{b. Lokasi Penelitian}

Penelitian ini dilakukan di Wilayah Kabupaten Pangkep tepatnya berada di Kecamatan Labakkang terdiri atas 13 Desa/Kelurahan dan difokuskan pada wilayah Kelurahan Pudata Baji yang berjarak $3 \mathrm{~km}$ dari ibukota kecamatan dan $12 \mathrm{~km}$ dari Ibukota Kabupaten Pangkep dengan luas wilayah Kelurahan Pundata Baji seluas 5,22 $\mathrm{km} 2$.

Secara administrasi wilayah, Kelurahan Pundata Baji terdiri dari Lingkungan Pundata dan Lingkungan Maccini Baji, yang terdiri atas 4 (RW) dan 20 (RT). Kelurahan Pundata Baji memiliki luas wilayah 522,58 ha dengan jumlah penduduk sebanyak 46.440 jiwa, terdiri atas 21.881 jiwa penduduk laki-laki dan 24.559 penduduk perempuan. Lingkungan Pundata terletak di daratan sedangkan Lingkungan Maccini Baji terletak di Kawasan Pesisir. c. Populasi dan Sampel

Populasi adalah keseluruhan obyek penelitian. Studi atau penelitiannya juga disebut studi populasi atau studi sensus (Arikunto,2010:173). Adapun populasi dalam penelitian ini sebanyak 4.025 jiwa berdasarkan jumlah penduduk Kelurahan Pundata Baji Kecamatan Labakkang tahun 2018

Sampel menurut Arikunto (2010:174) adalah sebagian atau wakil populasi yang diteliti sedangkan menurut Sugiyono (2013:116), sampel adalah bagian dari jumlah dan karakteristik yang dimiliki oleh populasi. Sampel yang digunakan dalam penelitian ini adalah masyarakat Kelurahan Pundata Baji Kecamatan Labakkang. Sampel yang digunakan dalam penelitian ini sebanyak 98 sampel.

\section{d. Teknik Pengumpulan Data}

Populasi dalam penelitian ini yaitu bersumber dari keseluruhan jumlah penduduk Kelurahan Pundata Baji yaitu sebesar 4.025 Jiwa. Sehingga teknik sampling dalam penelitian ini adalah probability sampling dengan metode stratified random sampling yaitu Metode Pengambilan sampel acak berstrata mengambil sampel berdasarkan tingkat strata pendidikan atau mata pencaharian.

e. Variabel Penelitian

Variabel penelitian adalah segala sesuatu yang berbentuk apa saja yang ditetapkan oleh peneliti untuk dipelajari sehingga diperoleh informasi tentang hal tersebut, kemudian ditarik kesimpulannya (Sugiyono, 2010).

1. Untuk menjawab rumusan masalah pertama terkait bagaimana karakteristik ketimpangan sosial ekonomi pada kawasan pesisir Kecamatan Labakkang, maka digunakan variabel penelitian yaitu tingkat pendapatan antar masyarakat di Kelurahan Pundata Baji Kecamatan Labakkang. Indeks Gini adalah ukuran umum untuk yang digunakan untuk mengetahui distribusi pendapatan atau kekayaan yang menunjukkan seberapa meratanya pendapatan dan kekayaan yang didistribusikan diantara populasi. Indeks Gini berkisar antara 0 sampai 1 . Jika menunjukkan nilai 0 , maka distribusi digambarkan sangat merata dengan asumsi bahwa setiap orang memiliki jumlah penghasilan atau kekayaan sama persis. Jika menunjukkan nilai atau angka 1 (satu) maka distribusi pendapatan akan timpang sempurna, dengan asumsi bahwa satu orang memiliki pendapatan yang tinggi dan yang lainnya memiliki pendapatan sangat kurang.

2. Untuk menjawab rumusan masalah kedua terkait adakah pengaruh secara signifikan perkembangan kawasan pesisir terhadap kondisi sosial ekonomi masyarakat, maka digunakan variabel penelitian untuk menguji sejauh mana pengaruh sebab akibat antara Variabel Faktor Penyebab (X) terhadap Variabel Akibatnya (Y). Penelitian ini menggunakan metode analisis regresi linear berganda karena variabel bebasnya terdiri lebih dari satu. Variabel yang mempengaruhi disebut Independent Variable (variabel bebas) dan variabel yang dipengaruhi disebut Dependent Variable (variabel terikat). Penelitian ini 
terdiri dari lima variabel bebas (independent) yaitu pendapatan $\left(\mathrm{X}_{1}\right)$, pendidikan $\left(\mathrm{X}_{2}\right)$, akses modal $\left(\mathrm{X}_{3}\right)$, sarana dan prasarana $\left(\mathrm{X}_{4}\right)$ dan pekerjaan $\left(\mathrm{X}_{5}\right)$, sedangkan variabel terikatnya (dependent) adalah kondisi sosial ekonomi masyarakat (Y).

f. Teknik Analisis Data

Untuk menjawab rumusan masalah dalam penelitian ini digunakan alat analisis terkait bagaimana karakteristik ketimpangan sosial ekonomi pada kawasan pesisir dan pengaruh secara signifikan perkembangan kawasan pesisir terhadap kondisi sosial ekonomi masyarakat di Kelurahan Pundata Baji Kecamatan Labakkang Kabupaten Pangkep. berikut;

Adapun alat analisis dalam penelitian ini sebagai

1. Rumusan masalah pertama pada penelitian ini yaitu bagaimana karakteristik ketimpangan sosial ekonomi pada kawasan pesisir dan pengaruh secara signifikan perkembangan kawasan pesisir, maka alat analisis menggunakan Koefisien Gini (Gini Ratio) atau Indeks Gini. Adapun rumusnva sebagai berikut;

$$
G R=1-\sum_{i=1}^{n} P_{i}\left(F_{i}+F_{i-1}\right)
$$

dimana,

- GR : Gini Ratio (Koefisien Gini)

- Pi : Frekuensi penduduk dalam kelas pengeluaran ke-i

- Fi : Frekuensi kumulatif dari total pengeluaran dalam kelas pengeluaran ke-i

- Fi-1 : Frekuensi kumulatif dari total pengeluaran dalam kelas pengeluaran ke (i-1)

2. Rumusan masalah yang kedua dalam penelitian ini menggunakan analisis regresi linier berganda yaitu hubungan secara linier antara dua atau lebih variabel independen $(\mathrm{X} 1, \mathrm{X} 2, \ldots, \mathrm{Xn})$ dengan variabel dependen $(\mathrm{Y})$. Dalam analisis regresi linear berganda, pengaruh satu variabel bebas terhadap variabel terikat dapat dibuat persamaan sebagai berikut

$\mathrm{Y}^{\mathfrak{c}}=\mathrm{a}+\mathrm{b} 1 \mathrm{X} 1+\mathrm{b} 2 \mathrm{X} 2+\ldots .+\mathrm{bnXn}$.

Keterangan:

$\mathrm{Y}=$ Variabel terikat

$\mathrm{a}=$ Konstanta (nilai $Y$ ' apabila $\mathrm{X} 1, \mathrm{X} 2, . . \mathrm{Xn}=0$ )

$\mathrm{b}=$ Koefisien regresi

$\mathrm{X}=$ Variabel bebas

\section{Hasil dan Pembahasan}

Hasil dan pembahasan analisis tingkat ketimpangan pendapatan dan pengaruh perkembangan pesisir wilayah penelitian. Pembahasan tersebut dijabarkan sebagai berikut:

a Karakteristik ketimpangan perkembangan kawasan pesisir terhadap kondisi sosial ekonomi masyarakat

1. Distribusi Pendapatan Masyarakat Kelurahan Pundata Baji

Hasil survei lapangan, sebagian besar masyarakat utamanya pada kawasan pesisir yang bermata pencaharian sebagai nelayan berada pada pendapatan dibawah rata-rata Rp. 1.000.000/bulan, kondisi tersebut mempengaruhi akan kebutuhan kondisi sosial ekonominya. Berdasarkan hasil analisis indeks gini ratio, total pendapatan untuk distribusi pendapatan masyarakat berdasarkan sampel penelitian yaitu sebanyak Rp. 92.300.000, dengan tingkat populasi sebesar $49,5 \%$, tingkat income sebesar $1,009 \%$, tingkat cummulative income sebesar 29,87\% dan tingkat Area Under the Lorenz sebesar 0,293. Untuk lebih jelasnya terkait distribusi pendapatan masyarakat di Kel. Pundata baji, sebaga berikut;

Tabel 1 Total distribusi pendapatan masyarakat Kelurahan Pundata Baji berdasarkan sampel penelitian

\begin{tabular}{cccccc}
\hline $\begin{array}{c}\text { Total } \\
\text { Individual }\end{array}$ & $\begin{array}{c}\text { Total Income } \\
\text { (Rp) }\end{array}$ & $\begin{array}{c}\% \\
\text { pop }\end{array}$ & $\begin{array}{c}\% \\
\text { inc }\end{array}$ & $\begin{array}{c}\text { Cumm } \\
\% \text { inc }\end{array}$ & $\begin{array}{c}\text { Area } \\
\text { Under the } \\
\text { Lorenz }\end{array}$ \\
\hline 98 & 92.300 .000 & 49,5 & 1,009 & 29,87 & 0,293773 \\
\hline Sumber : Hasil Analisis Penelitian, 2019
\end{tabular}

2. Analisis tingkat ketimpangan pendapatan masyarakat

Hasil perhitungan koefisien Gini yaitu pengukuran luas kurva yang menggambarkan distribusi pendapatan masyarakat kawasan pesisir Kecamatan Labakkang, adapun Area A sebesar 0,2062 dan area Gini sebesar 0,4125 maka dapat disimpulkan suatu pendapatan masyarakat dikatakan semakin merata jika nilai Koefisien Gini akan mendekati nol (0) sedangkan semakin tidak merata pendapatan masyarakat maka nilai Koefisien Gini-nya akan semakin mendekati angka 1 (satu) sehingga karakteristik ketimpangan sosial ekonomi pada kawasan pesisir Kecamatan Labakkang Kabupaten Pangkep berada pada nilai Koefisien $0,4<x<0,5$ yaitu $0,2062<x<0,4125$ dengan tingkat ketimpangan sedang.

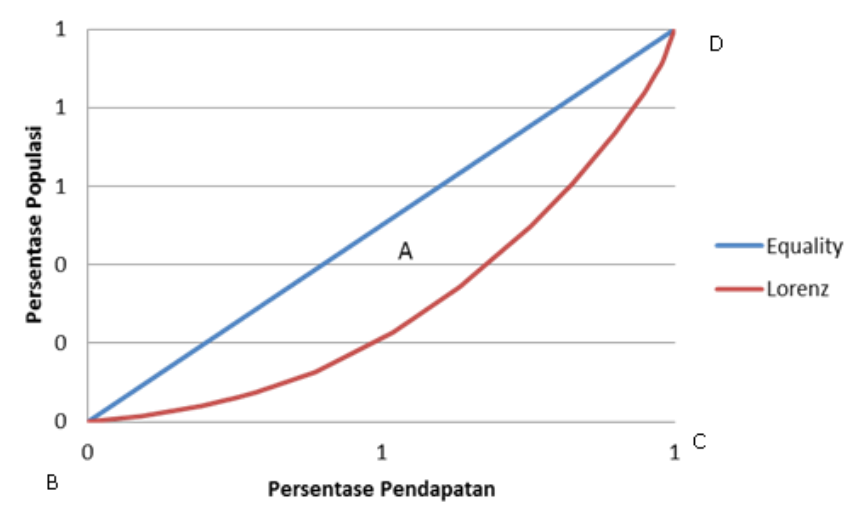

Gambar 1 Rasio perbandingan distribusi penduduk dan persentase pendapatan masyarakat

b Analisis pengaruh perkembangan kawasan pesisir terhadap kondisi sosial ekonomi masyarakat.

1. Analisis keakuratan data

Hasil uji normalitas dengan Kolmogorov-Smirnov Test diketahui nilai KSZ adalah 0,877 dan Asymp.sig. adalah $0,425>$ dari 0,05 , maka data memiliki distribusi normal. Untuk lebih jelasnya terkait uji normalitas, adalah; Histogram

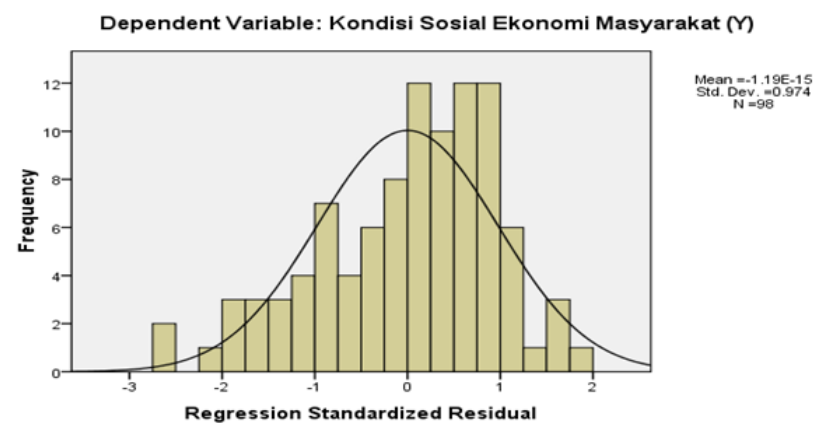

Gambar 2 Histrogram pada hasil Pengujian Kurva Uji t 
Normal P.P Plot of Regression Standardized Residual

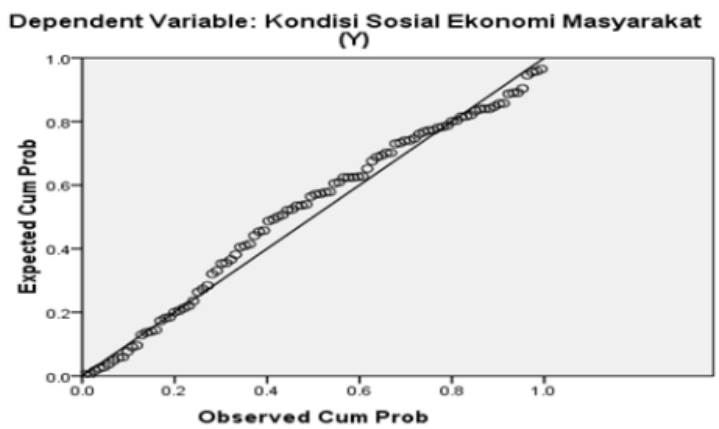

Gambar 3 Grafik normal P-P Plot standar regresi residu

3. Analisis faktor yang mempengaruhi perkembangan kawasan pesisir

Secara umum, sebanyak kurang lebih 160 Kepala Keluarga (KK) di Kelurahan Pundata Baji utamanya pada kawasan pesisir, sangat bergantung pada hasil laut sehingga masyarakat lebih dominan berprofesi sebagai nelayan yang pendapatanya tidak menentu untuk menghidupi kebutuhan ekonominya. Hasil analisis dengan uji t, dimana terdapat beberapa hipotesis yang memiliki pengaruh terhadap kondisi sosial ekonomi masyarakat pesisir Kelurahan Pundata Baji Kabupaten Pangkep yaitu hipotesis H2 dan $\mathrm{H} 4$ dikarenakan nilai sig. $<0,05$, atau $\mathrm{F}$ hitung $>\mathrm{F}$ tabel maka terdapat pengaruh variabel $X$ secara bersama terhadap variabel $\mathrm{Y}$, sedangkan hipotesis yang tidak memiliki pengaruh yaitu $\mathrm{H} 1, \mathrm{H} 3$ dan $\mathrm{H} 5$ dikarenakan nilai sig. $>0,05$, atau $\mathrm{F}$ hitung $<\mathrm{F}$ tabel maka tidak terdapat pengaruh variabel $\mathrm{X}$ secara bersama terhadap variabel $\mathrm{Y}$.

Tabel 2 Hasil Hipotesis Uji t

\begin{tabular}{|c|c|c|c|c|c|}
\hline \multicolumn{6}{|c|}{ Coefficients $^{\mathrm{a}}$} \\
\hline \multirow{2}{*}{ Model } & \multicolumn{2}{|c|}{$\begin{array}{c}\text { Unstandardized } \\
\text { Coefficients }\end{array}$} & \multirow{2}{*}{$\begin{array}{c}\begin{array}{c}\text { Standardized } \\
\text { Coefficients }\end{array} \\
\text { Beta }\end{array}$} & \multirow{2}{*}{$\mathrm{t}$} & \multirow{2}{*}{ Sig } \\
\hline & B & $\begin{array}{l}\text { Std. } \\
\text { Error }\end{array}$ & & & \\
\hline Constant & 3.668 & 2.893 & & 1.268 & .208 \\
\hline $\mathrm{X} 1$ & .057 & .110 & .054 & .514 & .608 \\
\hline $\mathrm{X} 2$ & .297 & .092 & .333 & 3.241 & .002 \\
\hline X3 & .085 & .118 & .083 & .719 & .474 \\
\hline X4 & .297 & .130 & .228 & 2.281 & .025 \\
\hline X5 & .110 & .116 & .105 & .949 & .345 \\
\hline
\end{tabular}

Sumber: Hasil Analisis Penelitian, 2019

Berdasarkan Tabel 2. hipotesis dengan uji t diatas, nilai constant sebesar 3,668 yang menunjukkan pengaruh positif variabel independen (Pendapatan, Pendidikan, Akses Modal, Prasarana Dan Sarana, Pekerjaan). Bila variabel indenpenden naik atau berpengaruh dalam satu satuan, maka variabel kondisi sosial ekonomi masyarakat akan naik atau terpenuhi. Diketahui nilai koefisien regresi (B) variabel Pendapatan $\left(\mathrm{X}_{1}\right)$ sebesar 0,057 atau 5,7 \%, variabel Pendidikan $\left(\mathrm{X}_{2}\right)$ sebesar 0,297 atau 29,7\%, variabel Akses Modal $\left(\mathrm{X}_{3}\right)$ sebesar 0,085 atau 8,5\%, variabel Sarana Dan Prasarana $\left(\mathrm{X}_{4}\right)$ sebesar 0,297 atau $29,7 \%$, dan variabel Pekerjaan $\left(\mathrm{X}_{5}\right)$ sebesar 0,110 atau $11,0 \%$ terhadap variabel kondisi sosial ekonomi masyarakat (Y) artinya jika variabel tersebut mengalami kenaikan satu satuan, maka kondisi sosial ekonomi masyarakat (Y) akan mengalami peningkatan koefisien bernilai positif yang artinya antara variabel $\mathrm{X}$ dan kondisi sosial ekonomi masyarakat (Y) berhubungan positif. Kenaikan variabel (X) akan mengakibatkan kenaikan pada kondisi sosial ekonomi masyarakat (Y).

Berdasarkan nilai Sig. untuk pengaruh variabel pendapatan $(\mathrm{X} 1)$ yaitu $0,608>0,05$ dan nilai t hitung $0,514<$ t tabel 1,98609 sehingga X1 ditolak yang artinya tidak terdapat pengaruh terhadap Y. Dengan demikian, tidak ada pengaruh perkembangan kawasan pesisir di Kelurahan Pundata Baji Kecamatan Labakkang terhadap kondisi sosial ekonomi masyarakat berdasarkan faktor pendapatan. Pada umumnya, sebagian besar pekerjaan utama yang bermukim di sekitar kawasan pesisir Kelurahan Pundata Baij adalah sebagai nelayan, adapun pendapatan masyarakat terkadang tidak menentu. Dengan adanya, kebijakan pembangunan kawasan pesisir dalam hal ini fasilitas dermaga di Kelurahan Pundata Baji, tidak mempengaruhi peningkatan ekonomi masyarakat, justru sangat mengangu aktivitas nelayan dikarenakan aktivitas bongkar muat barang di sekitar Dermaga Maccini Baji. Adapun kegitan lain, terkadang masyarakat sebagian besar beralih profesi juga sebagai buruh rumput laut yang pendapatannya kadang tidak menentu dikarenakan sangat bergantung pada faktor cuaca, selain itu adanya oknum pemilik modal yang bekerjasama dengan masyarakat pesisir untuk tangkapan hasil laut namun dengan hasil yang tidak seimbang sehingga perlunya sebuah wadah kegiatan masyarakat yang netral dalam memberdayakan masyarakat agar pendapatannya dapat terjamin melalui usaha dan keterampilannya.

Berdasarkan nilai Sig. pengaruh pendidikan (X2) yaitu $0,002<0,05$ dan nilai t hitung 3,241 > t tabel 1,98609, sehingga X2 diterima, maka terdapat pengaruh terhadap Y. Dengan demikian, ada pengaruh perkembangan kawasan pesisir di Kelurahan Pundata Baji Kecamatan Labakkang terhadap kondisi sosial ekonomi masyarakat berdasarkan faktor pendidikan. Adanya kebijakan pengembangan fasilitas oleh Pemerintah Daerah Kabupaten Pangkep, sangat memberikan dampak atau pengaruh terhadap anak anak untuk bersekolah. Adanya kebijakan pembangunan tersebut dalam hal ini peningkatan sarana pendidikan, sangat memberikan konstribusi terhadap peningkatan pendidikan di Kabupaten Pangkep dalam mendukung kesejahteraan masyarakat melalui pendidikan anak-anaknya. Sehingga diharapkan, dengan adanya pengembangan kawasan pesisir di Kelurahan Pundata Baji, sangat memberikan pengaruh kuat terhadap masyarakat untuk melanjutkan pendidikan yang lebih tinggi.

Berdasarkan nilai Sig. pengaruh akses modal (X3) yaitu $0,474>0,05$ dan nilai t hitung $0,719<\mathrm{t}$ tabel 1,98609 sehingga $X 3$ ditolak, maka tidak terdapat pengaruh terhadap Y. Dengan demikian, tidak ada pengaruh perkembangan kawasan pesisir di Kelurahan Pundata Baji Kecamatan Labakkang terhadap kondisi sosial ekonomi masyarakat berdasarkan faktor akses modal. Sejalan dengan kesimpulan tersebut, bahwa pemberian akses modal untuk peningkatan ekonomi masyarakat, utamanya pada kawasan pesisir di Kelurahan Pundata Baji tidak tepat sasaran. Adanya kebijakan pemerintah terhadap akses modal kepada masyarakat pesisir guna meningkatkan ekonomi masyarakat, namun tidak dimanfaatkan secara maksimal dikarenakan kurangnya pembinaan dan pelatihan keterampilan dalam 
mengelola akses modal, sehingga masyarakat memanfaatkan untuk tujuan jangka pendek. Disamping itu, keberadaan pemilik modal yang memanfaatkan masyarakat pesisir dalam pengelolaan potensi laut yang salah satunya usaha rumput laut, sedangkan upah yang diterima hanya Rp. 3.500/tali yang tentunya kurang mencukupi kebutuhan sehari-hari masyarakat pesisir di Kelurahan Pundata Baji Kecamatan Labakkang Kabupaten Pangkep. Maka kedepannya diperlukan sebuah pelatihan keterampilan kepada masyarakat yang tidak hanya mengandalkan modal dalam mengelola usaha namun adanya keterampilan lain yang dapat bersain dengan produk lokal untuk dipasarkan keluar daerah Kabupaten Pangkep selain bergantung hanya pada hasil laut.

Berdasarkan nilai Sig. pengaruh sarana dan prasarana (X4) yaitu $0,025<0,05$ dan nilai t hitung 2,281 > t tabel 1,98609, sehingga X4 diterima, maka terdapat pengaruh terhadap Y. Dengan demikian, ada pengaruh perkembangan kawasan pesisir di Kelurahan Pundata Baji Kecamatan Labakkang terhadap kondisi sosial ekonomi masyarakat berdasarkan faktor sarana dan prasarana. Adanya kebijakan Pemerintah pusat dan daerah terhadap peningkatan sarana dan prasarana melalui bantuan salah satunya yaitu dana desa, sangat memberikan dampak terhadap peningkatan ekonomi masyarakat. Ketersediaan fasilitas penunjang seperti sarana perdagangan, pendidikan, kesehatan memberikan konstribusi terhadap masyarakat dalam meningkatkan ekonominya. Maka kedepannya, perlunya pengawasan dalam pemanfaatan sarana dan prasarana sehingga masyarakat dapat menikmati hasil pembangunan kawasan pesisir di Kelurahan Pundata Baji.

Berdasarkan nilai Sig. pengaruh pekerjaan (X5) yaitu $0,345>0,05$ dan nilai $\mathrm{t}$ hitung $0,949<\mathrm{t}$ tabel 1,98609 sehingga X5 ditolak, maka terdapat pengaruh terhadap Y. Dengan demikian, tidak ada pengaruh perkembangan kawasan pesisir di Kelurahan Pundata Baji Kecamatan Labakkang terhadap kondisi sosial ekonomi masyarakat berdasarkan faktor pekerjaan. Sebagaimana diketahui, bahwa sebagian besar mata pencaharian utama masyarakat pesisir yaitu sebagai nelayan. Sehingga dengan adanya perkembangan kawasan pesisir salah satunya dalam hal peningkatan sarana dan prasarana tidak memberikan dampak kepada masyarakat untuk beralih profesi dikarenakan kurangnya keterampilan kepada masyarakat untuk pengelolaan potensi hasil laut. Diharapkan adanya pelatihan dan keterampilan kepada masyarakat dalam pengelolaan hasil potensi laut di Keluraha Pundata Baji sehingga dapat meningkatkan ekonomi masyarakat.

Berdasarkan dasar pengambilan keputusan dapat disimpulkan bahwa X2, X4 diterima yang berarti terdapat pengaruh terhadap Y sedangkan X1, X3 dan X5 ditolak, maka tidak adanya pengaruh terhadap Y. Adapun Standardized Coefficients yaitu pengaruh sumbangan efektif diberikan antara variabel (X1) terhadap (Y) sebesar 0,054 atau 5,4\%, variabel (X2) terdapat (Y) sebesar 0,333 atau 33,3\%, (X3) terhadap (Y) sebesar 0,083 atau 8,3\%, variabel (X4) terhadap (Y) sebesar 0,228 atau 22,8\%, variabel (X5) terhadap (Y) sebesar 0,105 atau 10,5\% .

\section{Hasil Pengaruh Secara Bersama}

Berdasarkan hasil "ANOVA', dibawah, dapat diketahui nilai signifikansi (Sig.) dalam uji F untuk pengaruh variable bebas secara simultan terhadap variable terikat adalah sebesar $0,000<0,05$ dan nilai $\mathrm{F}$ hitung
10,447 > F tabel 2,31, maka dapat disimpulkan bahwa H6 diterima yang berarti terdapat pengaruh pendidikan (X2), sarana dan prasarana (X4) secara bersama terhadap Kondisi Sosial Ekonomi Masyarakat (Y).

Tabel 3 Hasil Hipotesis H6 uji F

\begin{tabular}{lllllc}
\hline \multicolumn{7}{c}{ ANOVA $^{\mathrm{b}}$} \\
\hline \multirow{2}{*}{ Model } & $\begin{array}{c}\text { Sum of } \\
\text { Squares }\end{array}$ & \multicolumn{1}{c}{ df } & $\begin{array}{c}\text { Mean } \\
\text { Square }\end{array}$ & F & Sig. \\
\hline Regression & 254.950 & 5 & 50.990 & 10.447 & $.000 \mathrm{a}$ \\
Residual & 449.050 & 92 & 4.881 & & \\
\hline Total & 704.000 & 97 & & & \\
\hline
\end{tabular}

a. Predictors: (Constant), Pekerjaan (X5), Sarana Dan Prasarana (X4), Pendidikan (X2), Pendapatan (X1), Akses Modal (X3)

b. Dependent Variable: Kondisi Sosial Ekonomi Masyarakat (Y)

Sumber: Hasil Analisis Penelitian, 2019

\section{Nilai Pengaruh Secaa Bersama}

Berdasarkan hasil SPSS “'Model Summary" dibawah, diketahui nilai $\mathrm{R}$ square yaitu 0,362 . Nilai $\mathrm{R}$ Square 0,327 berasal dari pengkuadratan ' $R$ ', yaitu 0,602 × 0,602 = 0,362 . Besarnya angka koefisien detrminasi ( $\mathrm{R}$ Square) adal 362 atau sama dengan 36,2 \% yang mengandung bahwa variabel X2 dan X4 secara bersama-sama berpengaruh terhadap variabel kondisi sosial ekonomi masyarakat (Y) sebesar 36,2 \% sedangkan sisanya (100\% $36,2 \%=63,8 \%)$ dipengaruhi oleh variabel diluar persamaan regresi ini. Untuk lebih jelasnya sebagaimana pada tabel koefisien determinasi berikut ini;

Tabel 4 Koefisien diterminasi

\begin{tabular}{ccccc}
\hline \multicolumn{5}{c}{ Model Summary } \\
\hline Model & $\mathrm{R}$ & $\begin{array}{c}\mathrm{R} \\
\text { Square }\end{array}$ & $\begin{array}{c}\text { Adjusted } \\
\text { R Square }\end{array}$ & $\begin{array}{c}\text { Std. Error of the } \\
\text { Estimate }\end{array}$ \\
\hline 1 & $.602 \mathrm{a}$ & .362 & .327 & 2.20929 \\
\hline
\end{tabular}

a. Predictors: (Constant), Pekerjaan (X5), Sarana Dan Prasarana (X4),

Pendidikan (X2), Pendapatan (X1), Akses Modal (X3)

Sumber: Hasil Analisis Penelitian, 2019

6. Analisa Hasil Pengaruh

a) Pengaruh variabel Pendidikan

Standardized Coefficients pengaruh yang diberikan antara variabel pendidikan terhadap kondisi sosial ekonomi masyarakat sebesar 0,333 atau 33,3\%.

b) Pengaruh variabel sarana dan prasarana

Standardized Coefficients pada pengaruh yang diberikan antara variabel sarana dan prasarana terhadap kondisi sosial ekonomi masyarakat sebesar 0,228 atau $22,8 \%$.

c) Pengaruh variabel pekerjaan

Standardized Coefficients pada pengaruh yang diberikan antara variabel pekerjaan terhadap kondisi sosial ekonomi masyarakat sebesar 0,105 atau 10,5\%.

d) Pengaruh variabel Akses Modal

Standardized Coefficients pada pengaruh yang diberikan antara variabel akses modal terhadap kondisi sosial ekonomi masyarakat sebesar 0,83 atau $8,3 \%$.

e) Pengaruh variabel Pendapatan

Standardized Coefficients pada pengaruh yang diberikan antara variabel pendapatan terhadap kondisi sosial ekonomi masyarakat sebesar 0,054 atau 5,4\%.

c. Analisa karakteristik ketimpangan sosial ekonomi pada kawasan pesisir Kecamatan Labakkang Kabupaten Pangkep 
Hasil analisis indeks gini ratio, dapat disimpulkan bahwa Area A pada hasil kurva lorenz sebesar 0,2062 dan area Gini sebesar 0,4125 sehingga karakteristik ketimpangan sosial ekonomi pada kawasan pesisir Kecamatan Labakkang Kabupaten Pangkep berada pada nilai Koefisien $0,4<x<0,5$ yaitu $0,2062<x<0,4125$ dengan tingkat ketimpangan sedang. Dengan demikian, adanya tingkat ketimpangan dengan tingkat sedang di Kelurahan Pundata Baji, mengambarkan bahwa adanya kesenjangan pendapatan diantara masyarakat utamanya masyarakat yang bermukim pada wilayah pesisir yang mengantunkan hidupnya pada laut dan masyarakat yang bekerja sebagai pegawai, pengusaha atau pedagang yang pendapatannya jauh diatas rata rata masyarakat yang bekerja sebagai nelayan maupun buruh lepas.

d. Pembahasan analisis pengaruh secara signifikan perkembangan kawasan pesisir terhadap kondisi sosial ekonomi masyarakat Kecamatan Labakkang Kabupaten Pangkep.

Hasil analisis pengaruh pendapatan, maka tidak terdapat pengaruh pendapatan terhadap perkembangan sosial ekonomi masyarakat dikawasan pesisir Kelurahan Pundata Baji. Pendapatan nelayan Kelurahan Pundata Baji umunya ditentukan dengan cara bagi hasil, sehingga jarang sekali ada sistem gaji/upah tetap yang diterima oleh nelayan. Maka sistem yang digunaka akan dikurangi biaya operasional yang dikeluarkan pada waktu beroperasi, ditambah biaya penjualan hasil. Untuk kegiatan bagi hasil ini terkadang kurang menguntungkan para nelayan buruh di kelurahan Pundata Baji.

Berdasarkan hasil analisis pengaruh pendidikan, maka terdapat pengaruh pendidikan terhadap perkembangan sosial ekonomi masyarakat dikawasan pesisir kelurahan Pundata Baji. Secara umum program peningkatan SDM di Kabupaten Pangkep memiliki prestasi yang sangat baik, ditandai dengan penyaluran bantuan Pendidikan SPP terbanyak di Provinsi Sulawesi Selatan sehingga masyarakat sangat terdorong untuk melanjutkan Pendidikan agar memperbaiki perekonomian keluarga.

Berdasarkan hasil analisis pengaruh akses modal, maka tidak terdapat pengaruh askses modal terhadap perkembangan sosial ekonomi masyarakat dikawasan pesisir kelurahan Pundata Baji. Kerentanan masyarakat erat kaitannya dengan tingkat kemiskinan dan rendahnya kemampuan adaptasi (Sakuntaladewi, 2014). Kerentanan terhadap kondisi darurat seperti ketika terjadi perubahan musim yang sangat ekstrem, nelayan dengan keterbatasan sarana dan prasarana yang dimiliki tidak mampu bekerja, dan itu berarti tidak mendapatkan penghasilan. Serta ketidakberdayaan karena tidak mampu keluar dari kemiskinannya akibat terbatasnya keterampilan dan modal yang dimiliki. Modal usaha bagi nelayan antara lain kapal, alat tangkap, bahan bakar, alat pengawet, alat pengolah yang kesemuanya itu tidak sedikit jika dinominalkan.

Berdasarkan hasil analisis pengaruh sarana dan prasarana, maka terdapat pengaruh sarana dan prasarana terhadap perkembangan sosial ekonomi masyarakat dikawasan pesisir kelurahan Pundata Baji. Salah satu kemajuan pembangunan daerah adalah peningkatan terhadap pembangunan sarana dan prasarana. Pada wilayah Kelurahan
Pundata Baji, telah meningkatnya perbaikan prasarana dan sarana seiring kebijakan pemerntah pusat dan daerah terhadap peningkatan infrastruktur sehingga membantu kebutuhan masyarakat kelurahan Pundata Baji terhadap kegiatan perdagangan, pendidikan kesehatan, dan peribadatan sehingga fakto inilah yang mendorong peningkatan perkembangan kawasan pesisir terhadap kondisi sosial ekonomi masyarakat di Kelurahan Pundata Baji, Kecamatan Labakkang. Semakin pesatnya perkembangan teknologi, memudahkan masyarakat untuk mengakses berbagai informasi dikarenakan tersedianya akses telekomunikasi (internet) yang memudahkan didalam pengembangan ekonomi wilayah sehingga masyarakat dapat saling berinteraksi tanpa harus bertemu langsung. Selain itu, perkembangan jumlah penduduk yang tiap tahunnya meningkat sehingga perlunya penyediaan kebutuhan sarana dan prasarana di kawasan pesisir Kelurahan Pundata Baji.

Berdasarkan hasil analisis pengaruh pekerjaan, maka tidak terdapat pengaruh pekerjaan terhadap perkembangan sosial ekonomi masyarakat dikawasan pesisir kelurahan Pundata Baji. Pada umumnya, nelayan tradisional Pundata Baji sangat ulet menggunakan peralatan dengan keterbatasan dan kemampuan yang seadanya namun seringkali sulit untuk mengembangkan ke peralatan yang lebih modern. Kondisi ekonomi nelayan Pundata Baji yang cukup rendah disebabkan modal yang terbatas sehingga produktivitas terhadap hasil tangkapan ikan sangat kurang diakibatkan pengaruh musim yang tidak menentu, selain itu juga dengan jaminan pemasaran ikan yang tidak menentu diakibatkan sistem manajemen pemasaran yang kurang terarah.

\section{Kesimpulan}

Hasil penelitian dapat disimpulkan bahwa adanya tingkat ketimpangan yang sedang di Kelurahan Pundata Baji, mengambarkan bahwa adanya kesenjangan pendapatan diantara masyarakat utamanya masyarakat yang bermukim pada wilayah pesisir yang berprofesi sebagai nelayan dan masyarakat yang berprofesi sebagai pegawai, pengusaha atau pedagang yang pendapatannya jauh diatas rata rata masyarakat yang berprofesi sebagai nelayan maupun buruh lepas. Selannjutnya terdapat pengaruh secara signifikan perkembangan kawasan pesisir terhadap kondisi sosial ekonomi masyarakat Kecamatan Labakkang Kabupaten Pangkep.

\section{Daftar Pustaka}

Arikunto, S. 2010. Prosedur Penelitian Suatu Pendekatan Praktik. Jakarta: Rineka Cipta.

Badan Pusat Statistik, 2019, Buku Dalam Angka Provinsi Sulawesi Selatan Tahun 2018

Badan Pusat Statistik, 2019, Buku Dalam Angka Kabupaten Pangkep Provinsi Sulawesi Selatan Tahun 2018

Badan Pusat Statistik, 2019, Buku Dalam Angka Kecamatan Labakkang Kabupaten Pangkep Provinsi Sulawesi Selatan Tahun 2018.

Chambers, Robert. 1983. Pembangunan Desa Mulai dari Belakang. Jakarta: LP3ES. 
Hartono, Budiantoro, 2008, Analisis Ketimpangan Pembangunan Ekonomi di Provinsi Jawa Tengah, Tesis S.2 Program Pasca Sarjana. Undip. Semarang.

Nasaruddin, M. M., Manaf, M., \& Saleh, H. (2020). Pengaruh Pengembangan Kawasan Perumahan Terhadap Sosial Ekonomi dan Minimalisasi Gejala Urban Sprawl. Urban and Regional Studies Journal, 2(1), 15-24.

Roslinawati. 2013. Persepsi Masyarakat Terhadap Program Pemberdayaan Ekonomi Masyarakat Pesisir (Pemp) Di Kabupaten Donggala. Jurnal Academica Fisip Untad VOL.05 No. 02 Oktober 2013.

Sakuntaladewi, N, Sylviani. 2014. Kerentanan Dan Upaya Adaptasi Masyarakat Pesisir Terhadap Perubahan Iklim. Jurnal Penelitian Sosial dan Ekonomi Kehutanan Vol. 11 No. 4 Desember 2014, Hal. 281 293

Sjafrizal. 2008. Ekonomi Regional: Teori dan Aplikasi. Padang: Baduose Media.

Sugiyono. 2010. Metode Penelitian Pendidikan Pendekatan Kuantitatif, kualitatif, dan R\&D. Bandung: Alfabeta

Sugiyono . 2013. Metode Penelitian Pendidikan: Pendekatan Kuantitatif, Kualitatif, dan R\&D. CV. Alfabeta. Bandung.

Todaro, Michael P. 2004. Ekonomi Pembangunan Di Dunia Ketiga, Erlangga. Jakarta.

Utomo, T. W. W dan T. R. Hutauruk. 2014. Transformasi Sosial Ekonomi Masyarakat Pesisir dan Pedalaman di Kalimantan Mencari Sebuah Model Kebijakan Pembangunan yang Memberdayakan. 1-15. 